\title{
Vitamin D status of healthy adolescents from two states in Malaysia
}

\author{
Suhaimi Hussain ${ }^{1 *}$, Maged Elnajeh ${ }^{1}$, Muhammad Yazid Jalaludin², Fatimah Harun ${ }^{2}$ \\ From 8th APPES Biennial Scientific Meeting \\ Darwin, Australia. 29 October - 1 November 2014
}

Hypovitaminosis D is a widespread disorder across all age groups in developing countries. The prevalence of hypovitaminosis $\mathrm{D}$ varies from $30-90 \%$ depending on the cut off level used to define hypovitaminosis D. In Malaysia, Khor et. al found $35.3 \%$ of 402 primary school children aged $7-12$ years to have $25(\mathrm{OH}) \mathrm{D}$ level $<37.5 \mathrm{nmol} / \mathrm{L}$ and $37.1 \%$ have the level between $37.5-50 \mathrm{nmol} / \mathrm{L}$. If a broader definition of hypovitaminosis $<50 \mathrm{nmol} / \mathrm{L}$ is used then, the prevalence was as high as $74.6 \%$. The risk factors associated with hypovitaminosis D in developing countries are the same as in western countries. The most consistently reported risk factors are female gender, increased skin pigmentation, seasons/latitudes, obesity, concealing clothing style and vulnerable groups (neonates, preschool, elderly).

A total of 469 adolescents (107 PJ, $362 \mathrm{~KB}$ ) participated in the study. The mean age was $15.6+/-1.4$ years. Female gender contributed about $61.0 \%$ compared to male gender, $39.1 \%$. As for the race distribution, the proportion of Malay was $79.3 \%$, Chinese $17.7 \%$ and Indian $3.0 \%$. Teenagers from KB with family income < RM 1000 was higher $(37.8 \%$ cf $10.3 \%$; $\mathrm{P}<0.001)$. Adolescents from PJ was taller $(160.6 \mathrm{~cm}$ cf $156.3 \mathrm{~cm}$; $\mathrm{P}=0.02)$. The mean BMI was $21.0+/-4.4 \mathrm{kgm}^{2}$. The mean $25(\mathrm{OH})$ D was19.9+/-8.1, in which PJ had a higher level(21.0 cf 19.6) but the mean differences was not statistically significant. More than half (58\%) of adolescents had 25 $(\mathrm{OH}) \mathrm{D}<50 \mathrm{nmol} / \mathrm{L}$. The proportion of subjects with 25 $(\mathrm{OH}) \mathrm{D}<50 \mathrm{nmol} / \mathrm{L}$ was $60.2 \%$ in $\mathrm{KB}$ and $50.4 \%$ in PJ. With regard to the degree of $25(\mathrm{OH}) \mathrm{D}$ level, $52 \%$ had a level between $25.0-50.0 \mathrm{nmol} / \mathrm{L}, 6 \%$ had a level between $12.5-25.0 \mathrm{nmol} / \mathrm{L}$. None had a level $<12.5 \mathrm{nmol} / \mathrm{L}$.

Chinese had the highest mean of $25(\mathrm{OH}) \mathrm{D}(23.5+/-8.0$; $\mathrm{P}<0.001)$ compared to the other 2 races. From multiple

'Paediatric Department School of Medical Sciences Hospital University Science Malaysia, Kota Bharu, Kelantan, Malaysia

Full list of author information is available at the end of the article logistic regression, significant variables were age $(0.84 ; 95 \%$ CI :0.72,0.98), gender(boy) $(0.13 ; 95 \% \mathrm{CI} ; 0.08,0.19)$ and race(Chinese) $(0.30 ; 05 \% \mathrm{C} 1 ; 0.17,0.53)$. This study highlights a high prevalence of hypovitaminosis D among adolescents especially in younger adolescents, female and darker skin.

\section{Authors' details}

${ }^{1}$ Paediatric Department School of Medical Sciences Hospital University Science Malaysia, Kota Bharu, Kelantan, Malaysia. ${ }^{2}$ Department of Pediatrics, Faculty of Medicine, University of Malaya, Kuala Lumpur, Malaysia.

Published: 28 April 2015

doi:10.1186/1687-9856-2015-S1-P62

Cite this article as: Hussain et al:: Vitamin D status of healthy adolescents from two states in Malaysia. International Journal of Pediatric Endocrinology 2015 2015(Suppl 1):P62.

Submit your next manuscript to BioMed Central and take full advantage of:

- Convenient online submission

- Thorough peer review

- No space constraints or color figure charges

- Immediate publication on acceptance

- Inclusion in PubMed, CAS, Scopus and Google Scholar

- Research which is freely available for redistribution 